\title{
ENTREPRENEURIAL BUSINESS: GENETIC LOTTERY OR A CHOICE
}

\author{
Slavka NIKOLIĆ ${ }^{1}$, Tijana KOVIJANIĆC ${ }^{*}$, \\ Marijana MLADENOVIĆ ${ }^{2}$, Đorđe ĆELIĆ ${ }^{1}$ \\ ${ }^{1}$ Faculty of Technical Sciences, University of Novi Sad, Novi Sad, Serbia \\ ${ }^{2}$ College of Sports and Health, Belgrade, Serbia
}

Received 02 March 2019; accepted 14 October 2019

\begin{abstract}
Research dedicated to entrepreneurship has, from the very beginning, created a gender gap as it was mostly considered to be the masculine one. Studies with the main focus on psychological characteristics of entrepreneurs are mostly based on a comparison with other professionals, rarely approaching gender differences. Using the mixture of general personal and entrepreneurial traits, this study investigates entrepreneurial dilemma and answers the question whether entrepreneurship can or cannot be gendered, using a sample of potential entrepreneurs. Based on the multivariate analysis of variance, this study empirically proves that there are no statistically significant differences between the genders according to any criteria, except for the criterion of worry, which is more pronounced in women than in men. This study offers a good basis for the implementation of the existing models in different areas of entrepreneurship research, extending its understanding from the gender perspective. From the practical point of view, it provides a deeper understanding of entrepreneurial traits that might be critical for designing support and educational programs for enhancing (female) entrepreneurship.
\end{abstract}

Keywords: gender, entrepreneurship, personality, individual differences, Big Five, entrepreneurial traits.

JEL Classification: L26, D80, D91, J16.

\section{Introduction}

Entrepreneurship was always considered as a "male" domain, with an entrepreneur marked as a "hero and conqueror of the business world" (Knight, 2000). Even though that, now days, the stereotype of the dominant and efficient man, versus the restrained and submissive woman is often seen as hardly convincing, it still has the power to influence. Starting an entrepreneurial business, the woman is making a step into the world of opportunities and demonstrates unequivocal readiness to disturb such a long time ago established and long kept

*Corresponding author. E-mail: tijanasekulic@uns.ac.rs 
order in the world of men, conquering the world that belongs (or used to belong) only to man. The business is still dominated by male population, but times are changing, forcing the society, and above all, the academic community, to deal with the (new) paradigm of women. There is a growing number of women who assume the role of entrepreneurs and successfully implement their ideas into action.

Researchers were interested in exploring what encourages individuals to participate in entrepreneurship since 1960s and 1970s. What research had shown is that, certainly, external, socio-economic factors have great impact on this decision. However, what happens with internal factors such as personality traits remains insufficiently examined. Studies dedicated to entrepreneurship from a psychological perspective support the view that personality traits might help explain behavior differences between male and female entrepreneurs (Rauch \& Frese, 2007; Bernandino et al., 2018). Rauch and Frese (2007) make a distinction between general and specific personality traits and state that the studies which apply only the generally accepted traits (e.g. Big Five) to the research on the characteristics of entrepreneurs, cannot fully produce realistic results. Therefore, they focus on the traits that are cited as specific to entrepreneurs (e.g. innovativeness, need for success, risk appetite).

Extending this idea, the main goal of this paper is to investigate to which extent generally and specifically accepted personality traits of entrepreneurs, differ across the gender, using the sample of potential entrepreneurs. Ndubisi (2008) study was exploring entrepreneurial traits in context of usage of information and communication technologies. What they have found is that perseverance and flexibility scores favor male entrepreneurs, while risk taking propensity was an important determinant among female entrepreneurs. Furthermore, Muller and Thomas (2001) nine country study used traits approach and found no difference among male and female respondents regarding locus of control orientation, while innovativeness was more frequently observed males in the sample. On the other hand, Carland and Carland (1991) concluded that both male and female have higher intentions and preference for innovation and that no significant differences exist. Given that the literature is divided regarding the issue of traits, the authors of this study hope that their findings will enrich theoretical and empirical literature on entrepreneurial traits and gender differences. This study will also contribute to the literature stream dedicated to the psychology based research in entrepreneurship that focuses on links between individual level and venture creation helping to learn more about entrepreneurial behavior. Furthermore, by exploring these issues, this study will provide deeper understanding of the personality traits and give a good basis for the creation of the support and educational programs for enlarging the number of female entrepreneurs, at the first place.

The paper is structured as follows. At the first place, the concept of entrepreneurship from a gender perspective, including the overview of the psychological traits identified as essential for entrepreneurs has been introduced. In the next section, methodology and applied instruments are defined. The analysis of the results follows. Finally, the paper is concluded with a discussion of the findings in comparison with existing literature, including the limitations and implications for a future research. 


\section{Gendering entrepreneurship throughout theory}

The concept of entrepreneurship first appeared in academic circles during the 1930s (Schumpeter, 1934), with the first academic journal published in the 1960s (Jennings \& Brush, 2013). Entrepreneurship is a process whose key determinants are innovation, proactiveness and ability to take on business risk (Knight, 2000; Bhuian et al., 2005). An entrepreneur stands out from the circles of businessmen, managers and other professionals with his wisdom when going into risky ventures (Schumpeter, 1934), by determining the measure of acceptable risk.

The dominance of men in the world of entrepreneurship resulted in defining entrepreneurship as the "male" domain. At the end of the 1970s, among the respondents of a study on entrepreneurship there were also female entrepreneurs (Schwartz, 1976), so gender definition of entrepreneurship appears as one of the research questions. Proponents of feminism introduced the concept of "gender" in order to distinguish between biologically and socially constructed sex (Acker, 1992). Today, the concept of gender and sex is often equated and authors, when using these terms, mainly refer to men and women and not to the socially constructed sex (Ahl, 2006). A gender perspective is a mental (cognitive and affective) framework, often unconscious, colouring and conditioning perception, values and behavior and it can appear as a result of the interaction of biology and social influences (Bird \& Brush, 2002). The symbolic order of gender assigns the sphere of activity and creativity to the man, while passivity, adaptiveness and flexibility are associated with women (Bruni et al., 2004).

Many studies suggest that the past studies in the field of entrepreneurship constructed models and theories based on male entrepreneurs (Bird \& Brush, 2002; Marlow \& Martinez, 2018), which is why the validity and applicability of these models and conclusions on female entrepreneurs is called into question. Bruni et al. (2004) state that the male entrepreneurship model can be seen as universal and gender neutral when the emphasis on masculinity is invisible, and that female entrepreneurs will adapt to the seemingly gender-neutral set of values, while the men will adapt to the values that are "entrepreneurially" masculine. Starting from the supposition that entrepreneurship has a gender, it could be assumed that the application of these models is inappropriate in the field of female entrepreneurship and that they must be adapted and be different for different gender patterns. On the other hand, there are studies that show that research dealing with gender and entrepreneurship is limited to "male" entrepreneur models (Ahl, 2004; Bruni et al., 2004), highlighting differences between men and women (Ahl, 2006), ignoring the impact of socio-cultural factors (Saridakis et al., 2014), choice of the activity industry and the geographical position of the company (Kalnins \& Williams, 2014), which could explain possible differences. However, before getting into testing and implementation of existing models and theories, a clear and empirically supported basis should be set that entrepreneurship, in terms of psychological personality traits that define entrepreneurship, can or cannot be gendered.

\subsection{Psychological/Personality traits of entrepreneurs}

Gender stereotypes in the literature (Gunkel et al., 2007) define men as strong, active, competitive, with strong self-confidence, focusing on dominance, autonomy, aggression and economic success. On the other hand, women are generally associated with gentle roles, such 
as taking care of the home, children and people in general, so they are more into nurturing, sense of belonging, respect and quality of family life. Transferability of gender stereotypes to entrepreneurial tendencies suggests that women are too cautious, with an excessive aversion to risk, that they prioritize employees over economic activities and value the provision of services more than profitability (Greene et al., 2013). Men are more likely to value earnings, challenges, freedom, recognition and education, while women are more likely to value interpersonal relations, environment, safety, benefits and harmonization of work and family life. Domains in which women and men are similar are challenges at work, high wages, autonomy and progress at work and success (Gunkel et al., 2007).

Liberal political theory supports the view that social differences create inequality between men and women in the workplace. Consequently, if women develop the appropriate attributes and skills, they will be able to compete with men. Many studies suggest that men and women differ on the adoption of strategies, decisions, ways of working and thinking. However, the question is whether men and women differ in the traits which make a good entrepreneur. Personal characteristics such as risk tolerance, favouring autonomy and innovation are important because they influence the decision between entrepreneurship and employment (wage-salary work) (Fairlie \& Holleran, 2012)

The literature which deals with studying personal traits as determinants of entrepreneurship is relatively new and still evolving. Sexton (1989) argues that there is no psychological basis for the belief that women entrepreneurs will have lower attitude for business development than men. Personal traits can be defined as complex, genetically determined psychophysical structures that encourage and regulate individual experiences and actions. This means that traits can be seen as the causes of mental processes and behavioral processes (John et al., 2008). They can also be seen as descriptions of the level of the state or behavior of a person which vary depending on the circumstances arising accidentally or due to a voluntary choice made by the person (Fleeson, 2001). McCleland (1961) argues that the traits associated with high levels of need for success, search for challenges, taking responsibility for results and innovation, are defining characteristics of successful business starters. An entrepreneur is someone who demonstrates initiative and creative thinking, who can organize social and economic mechanisms so that resources show good results in practice, and someone who accepts the risk and potential failure (Hisrich, 1990).

Brandstatter (2011) argues that personal characteristics have a greater impact on entrepreneurs than on people of other professions. In order to determine the traits that characterize entrepreneurs, it is necessary to start from the five basic personality traits (ie. Big Five), defined by the five-factor personality model (Costa \& McCrae, 1992; Zhao \& Seibert, 2006) which includes: Emotional stability, Openness to experience, Conscientiousness, Extraversion, and Acceptance. The application of these factors in the field of entrepreneurship leads to the formation of the basic characteristics of the entrepreneurial role, such as starting an entrepreneurial life that is associated with self-determination and independence (emotional stability), finding new opportunities and ways for creation and development of enterprises (openness to experience), diligence and persistence in the realization of goals (motivation for achieving success as a component of conscientiousness), establishment of social contacts (extroversion) and risk taking (risk appetite, acceptance) (Brandstätter, 2011). Zhao and Seibert (2006) suggest that the 
personality structure is an important component in explaining the formation of new companies and entrepreneurial success, and that it is precisely the scale of the Big Five that is the basis for research which provides reliability and validity. Studies dealing with the five-factor model by comparing entrepreneurs and managers have shown that conscientiousness, openness to experience and extroversion are more dominant in entrepreneurs than in managers in relation to the agreeableness and neuroticism (Zhao \& Seibert, 2006; Zhao et al., 2010). Studies (Zhao \& Seibert, 2006; Rauch \& Frese, 2007; Zhao et al., 2010; Brandstätter, 2011), have shown that conscientiousness, openness to experience, extroversion and emotional stability have a positive impact on entrepreneurial intention and performance, while only acceptance as a trait had a negative impact on this variable. Innovation, as one of the main characteristics of entrepreneurs, is directly linked to openness to new experiences, creating a positive impact on the establishment of a business and its success. Emotional stability is associated with self-efficacy, tolerance to stress and locus of control, and it has been shown to have a positive impact on the establishment and success of business (Rauch \& Frese, 2007). This research suggests that the study of personal characteristics in a broad sense in the field of entrepreneurship is of great importance, given their strong impact on the establishment and development of business. Looking at the Big Five traits from gender perspective, Antoncic et al. (2015) study is interesting as they investigated interaction between Big Five personality traits and entrepreneurship, including the gender perspective. What they found is that there was no moderation gender effect on the entrepreneurship-personality factor relationship. With respect to the traits, they found that there was no significant difference among gender regarding the neuroticism, while men tend to score higher in openness, lower on conscientiousness, lower on extraversion, and lower on agreeableness. Murugesan and Jayavelu (2017) study only partially supports these results indicating that women score significantly higher levels of neuroticism, agreeableness, extraversion and consciousness than men.

By creating new and innovative entrepreneurial ventures, entrepreneurs operate in very uncertain environment in which results are unpredictable and risk of failure is high. Motivation and skill of the entrepreneur to assess the degree of uncertainty enables them to act entrepreneurially and cope with uncertainty (McMullen \& Shepherd, 2006). Therefore, the degree of tolerance for uncertainty is an extremely important entrepreneurial characteristic. Intolerance of uncertainty can be defined as a way in which a person adopts and observes information in uncertain situations, and responds with changes in behavior and cognitive and emotional reactions (Freeston et al., 1994). Under the high degree of uncertainty that establishment of a business entails, entrepreneurs are faced with the need for rapid decision making with the consequence of having to face the risk of correctness of a decision. Therefore, in addition to knowledge, expertise and skills, entrepreneurs must have certain personal qualities in order to successfully lead a business. Studies have shown that elevated levels of intolerance of uncertainty are associated with elevated levels of worry (Dugas et al., 2004; Berenbaum et al., 2008). MacLeod et al. (1991) defined worry as a cognitive phenomenon, linked to the future events for which there is uncertainty in the outcome, the future is viewed negatively and it is accompanied by a sense of anxiety. Precisely because worry is linked to the circumstances in which there is a great deal of uncertainty, this phenomenon has an impact on the decisions of entrepreneurs. 
Another important entrepreneurial traits is curiosity that can be defined as a positive emotional-motivational system connected with the identification, search and self-regulation of new opportunities and challenges (Kashdan et al., 2004). Curiosity encourages proactive, voluntary behavior as a response to the stimulus and activities induced by novelties, complexity and conflicts. A person with a higher degree of curiosity has a greater tendency to identify new opportunities, and this is precisely one of the characteristics that shape entrepreneurial activity. Research shows that entrepreneurs are very optimistic about their abilities and future outcomes (Busenitz \& Barney, 1997), and that they show greater disposition for optimism than employed people or managers.

The affect is a general term that refers to mood and emotion and it is one of the key personality traits that affects the processes occurring during the establishment of new companies. The environment in which entrepreneurs start their business is very unpredictable and subject to rapid changes and in such circumstances entrepreneurs cannot follow preestablished or already learned procedures and often have to devise new procedures on the fly. Research has shown that in these circumstances, the affect has a very significant effect on cognition and behavior (Baron, 2008), including the adoption of specific decisions and implementation of actions. The positive affect promotes effective strategies and efforts to solve the problems, while the negative affect leads to less effective strategies and avoiding problems (Baron, 2008). Positive emotions, such as joy and hope, lead to positive information and optimism, while negative emotions, such as fear, sadness and anger, cause pessimistic approach and negative information (Direnfeld \& Roberts, 2006). Positive emotions cause people to make positive assessments of situations (Carver, 2003) and take more risks. Positive emotions signal that the things are going well and that the environment is safe, which can encourage people to try something new. On the other hand, negative emotions signal that the things are not turning out as desired, and so people have to process the information carefully before making decisions.

Studies have shown that the possession of the internal locus of control is one of the significant determinants of entrepreneurship (Caliendo et al., 2011). People with a high level of internal locus of control believe that their own actions determine the course of future results and performance. Locus of control indicates the degree to which an individual believes that the causes of what is happening to them lie in external factors they cannot control (external locus of control), and the degree to which they believe they are personally responsible for what is happening in their lives (internal locus of control) (Joksimovic \& Janjetović, 2008). For entrepreneurs, it is extremely important to have the internal locus of control, given that they make decisions and create strategies for successful entrepreneurial business on the basis of the assessment of their own effectiveness.

Given the prevelant gaps in the literature relating personality traits and entrepreneurship from gender perspective, the present study is an extension of the previous literature on personality traits and entrepreneurship. The literature leads to the mixed results in this area. A waste number of studies found no significant differences between the genders. In accordance with this statement, Sexton and Bowman-Upton (1990) found no significant differences on five of the nine traits they measured (tendency to conform, interpersonal affect level, social adroitness, harm-avoidance, and need for succorance), while Chaganti's (1986) study showed 
no significant differences with respect to the need for achievement, autonomy, persistency, aggression, independence, nonconformity, goal orientation, self-confidence, leadership, and locus of control. Mueller and Thomas (2001) multi-country study found that man are scoring higher on innovative orientation than female, while there was no significant difference among the gender with respect to the internal locus of control orientation. No difference with respect to the internal locus of control was also proven by the Mueller (2004) study across the entire sample of seventeen countries. On contrary, Molino et al. (2018) study on personality found higher levels of self efficacy and internal locus of control in males. Carland and Carland (1991) study investigated personality traits (preference for innovation, propensity for risk taking and need for achievement) among entrepreneurs and managers, and found no difference in personality traits between female and male entrepreneurs, that were stronger than in managers. Masters and Meier (1988) also found no difference between a sample of male and female entrepreneurs in risk-taking propensity. On the other hand, in terms of risk taking propensity, the gender gap was positive with males scoring higher than females at Mueller's (2004) and Sexton and Bowman-Upton's (1990) studies.

A plethora of studies that is comparing personality/psychological traits of entrepreneurs to the others has been published, but not all of them took into account gender perspective. When investigating traits, there might be a gap between the actual traits and perceptions of those traits. Furthermore, sample may play an important part, as there might be a significant difference in results when including potential entrepreneurs and post-venture creation entrepreneurs. Most of the comparisons are made and conclusions were drawn about existing entrepreneurs instead of nascent or potential entrepreneurs. This study focuses on pre-venture issues, such as potential for entrepreneurship among women relative to man. Taking into account broad, Big Five, and entrepreneurial traits that stood out as the most important for determining potential entrepreneurs throughout the literature, the authors have set the null hypothesis that resolves entrepreneurial dilemma from gender perspective.

$\mathrm{H}_{0}$ : There is no psychological basis that male and female will differ with respect to neither broad nor entrepreneurial personality traits

\section{Method}

\subsection{Respondents and data collection procedure}

The survey was conducted on a sample of 231 students of the Faculty of Technical Sciences in Novi Sad (Republic of Serbia) and the Faculty of Production and Management, Trebinje - University of East Sarajevo (Bosnia and Herzegovina) (80\% of the sample consisted of students of the Faculty of Technical Sciences in Novi Sad). The sample consisted of $55.8 \%$ females and $44.2 \%$ males, 20.96 years old in average ( $\mathrm{SD}=1.82$; range $18-27$ years). The survey was carried out during classes, at the beginning or at the end of the lesson, with the respondents who signed an informed consent form. Participation in the survey was voluntary and did not include a reimbursement. The sample includes students from the final years in these two Universities, which are also engaged, to a large extent, into organizing entrepreneurial activities, such as StartUp Weekends, Competitions for the best entrepreneurial project and similar, that makes them a suitable environment for creation of potential entrepreneurs. 
Therefore, university students represent significant share of the pool of potential entrepreneurs. Muller and Thomas (2001) suggested that there is an increasing need for universitytrained entrepreneurs due to the dynamic technology and global competition growth as the business success will be dependent upon founder's education and training. Students are widely used as a sample in researching traits, especially their influence on entrepreneurial intention in different contexts (Muller \& Thomas, 2001; Gürol \& Atsan, 2006; Altinay et al., 2012; Farrukh et al., 2018; Van Ewijk \& Belghiti-Mahut, 2019). Sampling students also provides control over the testing environment due to their accessibility and convenience.

\subsection{Variables}

The study used the following variables: the independent variable - sex (male or female) and the dependent variable - psychological characteristics for which, based on the reviewed literature, it can be assumed they can operationally define the psychological profile of an entrepreneur: positive and negative affect, intolerance of uncertainty, tendency to worry, curiosity, optimism, self-efficacy, locus of control, conscientiousness, openness, neuroticism, extroversion and aggressiveness.

\subsection{Instruments}

For the purpose of determining and verifying individual differences and preferences of men and women in performing entrepreneurial business, instruments were used for assessing the degree of risk tolerance, optimism, worry, curiosity traits, openness to new experiences, internal locus of control, creativity and innovation.

All applied instruments were used in versions translated and adapted to the Serbian language. The following table provides a review of the used instruments (Table 1).

Table 1. Instruments

\begin{tabular}{|l|l|}
\hline \multicolumn{1}{|c|}{ Instrument } & \multicolumn{1}{|c|}{ Source } \\
\hline $\begin{array}{l}\text { Positive and Negative Affect Schedule (PANAS) } \\
20 \text { items describing feelings, e.g. PA: "Enthusiastic", "Proud" } \\
\text { and "Determined"; NA: "Unhappy", "Scared" and "Tense". }\end{array}$ & $\begin{array}{l}\text { Watson et al. (1988), Serbian } \\
\text { version (Mihić et al., 2014) }\end{array}$ \\
\hline $\begin{array}{l}\text { Intolerance of Uncertainty Scale - Short Form (IUS-12) } \\
\text { Shortened version of the Intolerance of Uncertainty Scale } \\
\text { questionnaire (IUS) based on prospective and inhibitory } \\
\text { anxiety. }\end{array}$ & $\begin{array}{l}\text { Carleton et al. (2007), Freeston } \\
\text { et al. (1994), Mihić et al. (2014) }\end{array}$ \\
\hline $\begin{array}{l}\text { The Penn State Worry Questionnaire 3 item version (PSWQ-3) } \\
\text { Shortened form of the original The Penn Sate Worry } \\
\text { Questionnaire. }\end{array}$ & $\begin{array}{l}\text { Meyer et al. (1990), Berle et al. } \\
\text { (2011) }\end{array}$ \\
\hline $\begin{array}{l}\text { Curiosity and Exploration Inventory-II (CEI-II) } \\
\text { The scale includes: Stretching subscale, referring to the } \\
\text { tendency of a person to seek out new experiences and } \\
\text { to expose themselves to situations that they consider } \\
\text { challengingand Embracing subscale, relating to the person's } \\
\text { readiness to accept uncertainty and novelty. }\end{array}$ & $\begin{array}{l}\text { Kashdan et al. (2004, 2009), } \\
\text { Jovanović and Jerković (2012) }\end{array}$ \\
\hline
\end{tabular}


End of Table 1

\begin{tabular}{|l|l|}
\hline \multicolumn{1}{|c|}{ Instrument } & \multicolumn{1}{c|}{ Source } \\
\hline $\begin{array}{l}\text { Personal Optimism Scale and the Self-Efficacy Optimism Scale } \\
\text { (POSO-9) } \\
\text { The scale measures two types of positive expectations: self- } \\
\text { efficacy and optimism. }\end{array}$ & $\begin{array}{l}\text { Gavrilov-Jerković et al. (2013), } \\
\text { Schweizer and Koch (2001) }\end{array}$ \\
\hline $\begin{array}{l}\text { Scale of externality } \\
\text { Scale is designed for measuring locus of control or orientation } \\
\text { of a person towards themselves and their own behavior. }\end{array}$ & $\begin{array}{l}\text { Bezinović and Savčić (1989), } \\
\text { Joksimovic and Janjetović (2008) }\end{array}$ \\
\hline $\begin{array}{l}\text { Big Five Plus Two questionnaire (VP+2) } \\
\text { Seven personality dimensions: Neuroticism, Extraversion, } \\
\text { Openness, Conscientiousness, Aggressiveness (as the opposite } \\
\text { of Agreeableness), Positive valence and Negative valence. }\end{array}$ & $\begin{array}{l}\text { Smederevac et al. (2010), } \\
\text { Čolović et al. (2014) }\end{array}$ \\
\hline
\end{tabular}

\section{Can we gender entrepreneurship: study results}

Statistical analysis of the data using multivariate analysis of variance (MANOVA) showed that there are no statistically significant gender differences among the tested variables (Table 3). By testing the reliability of used scales it was established that all the scales possess good reliability, except for the subscale of optimism, which showed slightly poorer reliability with internal consistency reliability coefficient $\alpha=0.65$. Table 2 shows the indicators of reliability of the scales.

The value of the multivariate analysis of variance (MANOVA) for testing differences by gender $(1-\mathrm{m}, 2-\mathrm{f})$ with respect to all the variables listed to be tested in the study is shown in

Table 2. Reliability of the scales

\begin{tabular}{|c|c|}
\hline & Cronbach alpha \\
\hline PA - positive affect & 0.77 \\
\hline NA - negative affect & 0.82 \\
\hline IUS - intolerance of uncertainty & 0.82 \\
\hline PSWQ - worry & 0.84 \\
\hline CEI - curiosity & 0.86 \\
\hline OPT - optimism & 0.65 \\
\hline SE - self-efficacy & 0.76 \\
\hline LK - locus of control & 0.82 \\
\hline SAV - conscientiousness & 0.75 \\
\hline $\mathrm{PV}$ - positive valence & 0.75 \\
\hline OTV - openness & 0.75 \\
\hline $\mathrm{NV}$ - negative valence & 0.85 \\
\hline NEU - neuroticism & 0.82 \\
\hline EXT - extraversion & 0.83 \\
\hline AGR - aggressiveness & 0.81 \\
\hline
\end{tabular}


Table 3. What could be concluded is that there are no gender differences between men and women in susceptibility to experiencing positive and negative affect, intolerance of uncertainty, curiosity, optimism, self-efficacy, externalization of control, as well as in the case of all seven dimensions of personality $\left(\mathrm{H}_{0}\right)$. In this study, gender differences are registered only in the case of worry $(\mathrm{F}=5.11, \mathrm{p}=0.03)$. It turned out that the women are more likely to worry $(\mathrm{M}=2.69, \mathrm{SD}=1.07)$ than men $(\mathrm{M}=2.38, \mathrm{SD}=0.97)$, but the difference is almost negligible.

Looking at the arithmetic means of the chosen criteria, it could be observed that both men and women scored a higher level of positive affect and curiosity compared to other positive emotions. Furthermore, the personality traits that the literature also mentions as being dominant for entrepreneurs - openness, conscientiousness and extraversion - turned out to be significant in the sample as well.

Table 3. Multivariate analysis of variance (MANOVA): testing differences by gender

\begin{tabular}{|c|c|c|c|c|c|c|}
\hline & Gender & $\mathrm{N}$ & M & SD & $\mathrm{F}$ & $\mathrm{p}$ \\
\hline \multirow{2}{*}{$\begin{array}{l}\text { Positive affect } \\
\text { (PANAS) }\end{array}$} & 1 & 102 & 3.66 & 0.53 & \multirow{2}{*}{1.67} & \multirow{2}{*}{0.20} \\
\hline & 2 & 128 & 3.57 & 0.50 & & \\
\hline \multirow{2}{*}{$\begin{array}{l}\text { Negative affect } \\
\text { (PANAS) }\end{array}$} & 1 & 102 & 1.89 & 0.58 & \multirow{2}{*}{1.76} & \multirow{2}{*}{0.19} \\
\hline & 2 & 128 & 1.99 & 0.57 & & \\
\hline \multirow{2}{*}{$\begin{array}{l}\text { Intolerance of } \\
\text { uncertainty (IUS) }\end{array}$} & 1 & 102 & 2.72 & 0.64 & \multirow{2}{*}{0.41} & \multirow{2}{*}{0.52} \\
\hline & 2 & 128 & 2.67 & 0.69 & & \\
\hline \multirow{2}{*}{ Worry (PSWQ) } & 1 & 102 & 2.38 & 0.97 & \multirow{2}{*}{5.11} & \multirow{2}{*}{0.03} \\
\hline & 2 & 128 & 2.69 & 1.07 & & \\
\hline \multirow{2}{*}{ Curiosity (CEI) } & 1 & 102 & 3.54 & 0.73 & \multirow{2}{*}{0.01} & \multirow{2}{*}{0.94} \\
\hline & 2 & 128 & 3.53 & 0.73 & & \\
\hline \multirow{2}{*}{ Optimism (POSO-9) } & 1 & 102 & 2.25 & 0.57 & \multirow{2}{*}{0.09} & \multirow{2}{*}{0.77} \\
\hline & 2 & 128 & 2.27 & 0.56 & & \\
\hline \multirow{2}{*}{$\begin{array}{l}\text { Self-efficacy } \\
\text { (POSO-9) }\end{array}$} & 1 & 102 & 2.17 & 0.42 & \multirow{2}{*}{0.68} & \multirow{2}{*}{0.41} \\
\hline & 2 & 128 & 2.12 & 0.46 & & \\
\hline \multirow{2}{*}{$\begin{array}{l}\text { Externalization of } \\
\text { control }\end{array}$} & 1 & 102 & 1.73 & 0.84 & \multirow{2}{*}{0.09} & \multirow{2}{*}{0.77} \\
\hline & 2 & 128 & 1.76 & 0.81 & & \\
\hline \multirow{2}{*}{ Conscientiousness } & 1 & 102 & 3.37 & 0.66 & \multirow{2}{*}{0.04} & \multirow{2}{*}{0.85} \\
\hline & 2 & 128 & 3.39 & 0.67 & & \\
\hline \multirow{2}{*}{ Positive valence } & 1 & 102 & 3.17 & 0.74 & \multirow{2}{*}{1.40} & \multirow{2}{*}{0.24} \\
\hline & 2 & 128 & 3.06 & 0.68 & & \\
\hline & 1 & 102 & 3.61 & 0.65 & 11 & \\
\hline Openness & 2 & 128 & 3.74 & 0.67 & 2.11 & 0.15 \\
\hline Neoative valence & 1 & 102 & 2.21 & 0.81 & 345 & 007 \\
\hline & 2 & 128 & 2.01 & 0.80 & & \\
\hline Nouraticism & 1 & 102 & 2.62 & 0.80 & 308 & 008 \\
\hline Neuroticism & 2 & 128 & 2.44 & 0.77 & 3.08 & 0.08 \\
\hline Fytrayercion & 1 & 102 & 3.61 & 0.75 & 150 & 020 \\
\hline Extraversion & 2 & 128 & 3.72 & 0.71 & 1.00 & 0.22 \\
\hline Agoressiveness & 1 & 102 & 2.71 & 0.79 & 008 & 078 \\
\hline Aggressiventess & 2 & 128 & 2.68 & 0.78 & & \\
\hline
\end{tabular}


Descriptive indicators of correlation between the studied variables show that the correlations between the variables used in the study are expected and that they correspond to the direction and strength of the connection between these constructs obtained in previous studies (Table 4). The distributions of all variables used in the study do not significantly differ from the normal distribution (the values of skewness and kurtosis do not exceed 1).

As it could be expected, a higher level of intolerance of uncertainty leads to a decline in the positive and a growth in the negative affect. The same is observed with worry, which in addition to the negative affect, also shows a positive correlation with intolerance of uncertainty. Positive characteristics such as curiosity, optimism and self-efficacy showed a statistically significant positive correlation with the positive affect as well as among themselves. Negative emotions, such as fear and anger, lead to a high level of uncertainty and limited control over events. Among the positive emotions, hope is related to the high level of uncertainty about the outcomes which are considered to be controlled by the situation in which they arise, and causes fear.

Testing the degree of curiosity did not show a statistically significant association with the negative affect, intolerance of uncertainty and worry. On the other hand, a higher degree of optimism negatively affects the three above-mentioned variables. Self-efficacy is negatively correlated with the negative affect and concern, while the association with intolerance of uncertainty has not proven to be statistically significant. The degree of externalization, as a measure of locus of control does not have a statistically significant correlation with the positive affect, curiosity and self-efficacy, while on the other hand it has a positive effect on the negative affect (lower statistical significance), intolerance of uncertainty and worry, as well as a negative effect on optimism. This means that a higher external locus of control plays a part in strengthening the negative emotions such as worry or intolerance of uncertainty, lowering the level of optimism.

When talking about the Big Five personality characteristics, a higher degree of conscientiousness leads to higher levels of positive affect, optimism and self-efficacy, while it shows a statistically significant negative correlation with the negative affect. Openness has a statistically significant correlation with the positive affect, curiosity, self-efficacy, conscientiousness and positive valence. Elevated levels of neuroticism are accompanied by lower levels of optimism, self-efficacy, conscientiousness and openness, while on the other hand it shows a positive correlation with the negative affect, intolerance of uncertainty, worry, externalization and negative valence. A higher degree of extraversion positively affects the positive affect, intolerance of uncertainty, curiosity, optimism, self-efficacy, externalization, conscientiousness, positive valence and openness, while it is negatively correlated with neuroticism. The fifth characteristic, aggressiveness, showed a positive correlation with the negative affect, intolerance of uncertainty, worry, externalization, positive and negative valence, neuroticism and extraversion, while it showed a negative correlation with optimism and conscientiousness. 


\begin{tabular}{|c|c|c|c|c|c|c|c|c|c|c|c|c|c|c|c|c|c|c|c|c|c|c|}
\hline$\stackrel{2}{2}$ & & & & & & & & & & & & & & & & & & - & iे & $\begin{array}{l}\infty \\
\stackrel{0}{0}\end{array}$ & $\bar{\alpha}$ & \\
\hline$\underset{\Xi}{ \pm}$ & & & & & & & & & & & & & & & & & - & \begin{tabular}{l}
\multirow{0}{0}{} \\
$\stackrel{0}{0}$
\end{tabular} & $\begin{array}{l}\hat{\sigma} \\
\dot{m}\end{array}$ & $\stackrel{m}{\stackrel{n}{0}}$ & $\tilde{\alpha}$ & \\
\hline$\underline{\sim}$ & & & & & & & & & & & & & & & & $\neg$ & 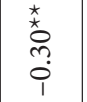 & $\begin{array}{l}\stackrel{\star}{\star} \\
\stackrel{F}{+} \\
0\end{array}$ & กֶ. & $\begin{array}{l}\infty \\
\stackrel{0}{0}\end{array}$ & $\alpha$ & \\
\hline 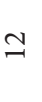 & & & & & & & & & & & & & & - & & 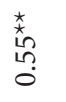 & $\begin{array}{l}\text { ò } \\
\stackrel{+}{0}\end{array}$ & $\begin{array}{l}\stackrel{\star}{\star} \\
\stackrel{+}{+} \\
\stackrel{0}{0}\end{array}$ & $\vec{\sim}$ & $\begin{array}{l}\infty \\
0 \\
0\end{array}$ & $\stackrel{L}{\infty}$ & \\
\hline$\exists$ & & & & & & & & & & & & & - & 齐 & & 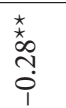 & $\begin{array}{l}\stackrel{x}{\star x} \\
\stackrel{n}{n} \\
0 \\
0\end{array}$ & $\begin{array}{l}\dot{0} \\
\dot{0}\end{array}$ & $\begin{array}{l}\infty \\
0 \\
\dot{r}\end{array}$ & : & tr & \\
\hline$\stackrel{ }{\circ}$ & & & & & & & & & & & & - & $\stackrel{\star \star \star}{\star}$ & $\frac{\sqrt{x}}{2}$ & & $\stackrel{\hat{O}}{\circ}$ & 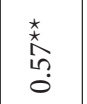 & $\begin{array}{l}\stackrel{\star}{*} \\
\stackrel{\infty}{0} \\
\stackrel{0}{0} \\
0\end{array}$ & $\vec{m}$ & ㅅ. & 占 & \\
\hline$a$ & & & & & & & & & & & - & 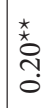 & 至 & 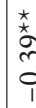 & & 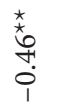 & $\begin{array}{l}\stackrel{\star}{\star} \\
\stackrel{\star}{\hat{n}} \\
\stackrel{0}{0}\end{array}$ & $\begin{array}{l}\stackrel{\star \star x}{\star} \\
\stackrel{\sim}{*} \\
0 \\
1\end{array}$ & $\begin{array}{l}\infty \\
m \\
m\end{array}$ & $\begin{array}{l}0 \\
0 \\
0\end{array}$ & 占 & \\
\hline$\infty$ & & & & & & & & & - & & $\begin{array}{l}\text { tr } \\
\stackrel{0}{0}\end{array}$ & 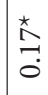 & $\begin{array}{l}+ \\
0 \\
0 \\
\end{array}$ & $\frac{t}{c}$ & & $\begin{array}{l}\stackrel{\star}{\star} \\
\stackrel{\infty}{\infty} \\
\stackrel{0}{0}\end{array}$ & $\stackrel{\stackrel{\star}{\star}}{\stackrel{2}{a}}$ & 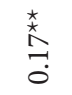 & 孛 & $\begin{array}{c}\approx \\
\infty \\
0 \\
0\end{array}$ & $\alpha$ & \\
\hline$n$ & & & & & & & & - & a & & 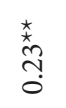 & 齐 & 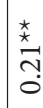 & $\bar{c}$ & & 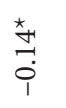 & 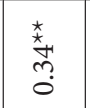 & $\begin{array}{l}\overrightarrow{0} \\
\dot{0}\end{array}$ & $\frac{n}{i}$ & $\underset{:}{\stackrel{H}{0}}$ & v & \\
\hline 6 & & & & & & & - & 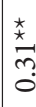 & 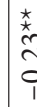 & & 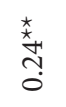 & $\stackrel{\star}{m}$ & L & $\bar{i}$ & & 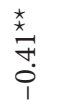 & $\stackrel{\star}{\stackrel{*}{\leftrightarrows}}$ & 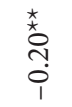 & ָ̊ & مْ & b & \\
\hline in & & & & & - & & \begin{tabular}{l}
$\stackrel{\star x}{\star}$ \\
\multirow{2}{*}{} \\
0
\end{tabular} & 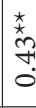 & c & & $\vec{F}$ & 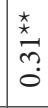 & 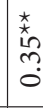 & $\frac{2}{c}$ & & $\ddot{0}$ & $\begin{array}{l}\stackrel{\star \star}{\star} \\
\stackrel{\text { N }}{0}\end{array}$ & $\overrightarrow{0}$ & $\begin{array}{l}n \\
n \\
n\end{array}$ & $\stackrel{N}{N}$ & $\mathscr{c}$ & \\
\hline H & & & & - & $\bar{c}_{i}$ & $\dot{b}$ & $\begin{array}{l}\stackrel{t}{*} \\
\stackrel{1}{L} \\
\stackrel{9}{0} \\
1 \\
1\end{array}$ & 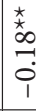 & $\frac{\hat{x}}{\partial}$ & & $\begin{array}{l}n \\
0 \\
\dot{\varphi}\end{array}$ & $\begin{array}{l}m \\
0 \\
0\end{array}$ & $\exists$ & 0 & & 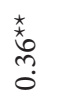 & $\begin{array}{l}\infty \\
\stackrel{0}{0}\end{array}$ & 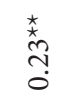 & $\begin{array}{l}10 \\
10 \\
i\end{array}$ & $\underset{\sim}{\stackrel{H}{0}}$ & a & \\
\hline$m$ & & & - & 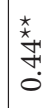 & $\begin{array}{l}a \\
c \\
i\end{array}$ & b. & 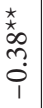 & $\begin{array}{l}8 \\
8 \\
\dot{8} \\
1\end{array}$ & 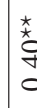 & & $\stackrel{\text { L }}{0}$ & 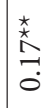 & $\stackrel{9}{\circ}$ & $\frac{1}{0}$ & & 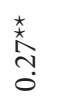 & $\begin{array}{l}\stackrel{\star}{\star} \\
\stackrel{\infty}{\infty} \\
\stackrel{1}{*}\end{array}$ & $\begin{array}{l}\stackrel{\star}{\star} \\
\stackrel{\text { N̦ }}{0}\end{array}$ & $\begin{array}{l}\hat{\sigma} \\
\text { i }\end{array}$ & : & $a$ & \\
\hline 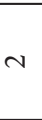 & & - & 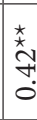 & 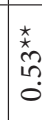 & $\begin{array}{c}\infty \\
c \\
c\end{array}$ & bे & 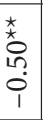 & 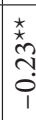 & ț & & 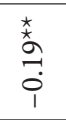 & $\begin{array}{l}0 \\
0 \\
0 \\
0\end{array}$ & 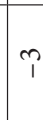 & 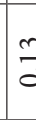 & & 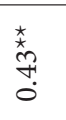 & $\begin{array}{l}\ddot{0} \\
0 \\
0\end{array}$ & $\begin{array}{l}\stackrel{\star}{\star} \\
\stackrel{\infty}{N} \\
\stackrel{0}{0}\end{array}$ & $\stackrel{2}{\Omega}$ & $\begin{array}{l}\infty \\
1 ? \\
0 \\
0\end{array}$ & $a$ & \\
\hline$\neg$ & - & 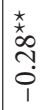 & 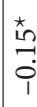 & $\begin{array}{l}\text { t. } \\
\text { th } \\
\\
0 \\
1\end{array}$ & 齐 & & $\begin{array}{l}\stackrel{\star x}{*} \\
\stackrel{+}{t} \\
\stackrel{0}{0}\end{array}$ & 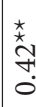 & $\begin{array}{c}n \\
c \\
c\end{array}$ & & 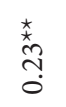 & 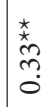 & 吂 & $\frac{b}{c}$ & & $\stackrel{\sim}{\stackrel{i}{+}}$ & 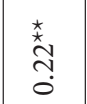 & oे & $\vec{b}$ & กิ & 옹 & \\
\hline & $\begin{array}{l}\overleftrightarrow{\Omega} \\
-\end{array}$ & $\begin{array}{l}\overleftrightarrow{Z} \\
\dot{z}\end{array}$ & $\begin{array}{l}? \\
\dot{m}\end{array}$ & : & 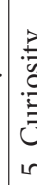 & Jै & 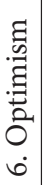 & 点 & II & & 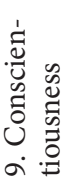 & $\vec{a}$ & 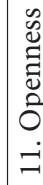 & z & & 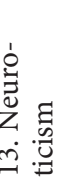 & 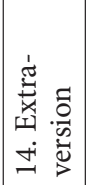 & 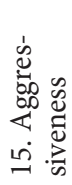 & 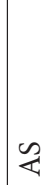 & क & $\varangle$ & \\
\hline
\end{tabular}




\section{Discussion}

As stated previously, this study empirically proves that there are no statistically significant differences between the genders according to any criteria, except for the criterion of worry, which is more pronounced in women than in men. Gender differences have not been found in terms of the positive affect (PA), which is in correlation with the results obtained in studies performed in America (U.S.) (Watson \& Clark, 1999). On the other hand, the survey conducted in Serbia showed a higher level of PA in men than in women (Mihić et al., 2014), which contradicts obtained results. This difference can be explained by a different sample that was used. Namely, the aforementioned study, in addition to the students of the University of Novi Sad, used older population (age range 18-50+), while this study tested PA only on a population of students. Even tough the use of a students' sample might be considered as a limitation and downside, many studies are using students as good representatives of potential entrepreneurs for testing different factors and characteristics related to entrepreneurship (e.g. Knatko et al., 2016; Almobaireek \& Manolova, 2013).

Entrepreneurs are working in dynamic environments with high level of uncertainty that can lead to higher levels of anxiety and stress. In order to come with these emotions, selfefficacy and optimism are playing an important role. Therefore, high entrepreneurial selfefficacy combined with a high dispositional optimism may lead to overconfidence and in turn to excessive risk-taking and other ineffective strategies (Palmer et al., 2019). The ability of an entrepreneur to assess the degree of uncertainty is extremely important given the need to make quick decisions in situations that are unpredictable and highly risky. As mentioned previously, the high level of intolerance of uncertainty may significantly affect the problemsolving skills. This research has shown that a high level of intolerance of uncertainty is associated with high levels of negative affect, worry and externalization. The results showing a statistically significant association between elevated levels of intolerance of uncertainty with high levels of worry, support the previous studies that have obtained the same results. Regarding the personality traits, higher levels of neuroticism, extroversion and aggressiveness are associated with higher levels of intolerance of uncertainty, which is to be expected. Entrepreneurs with high levels of neuroticism are more prone to irrational ideas and find it hard to deal with stress, so it is logical that they will have increased intolerance of uncertainty. Likewise, a person with pronounced aggressiveness will have a low level of altruism, will be competitive-minded and self-centered, so they will also face with a high degree of intolerance of uncertainty. Extroversion is a feature that has proved to be dominant in entrepreneurs, given that it refers to the expansion of the network of contacts and sociability. Leutner et al. (2014) showed that extraverted individuals are more likely to engage in different entrepreneurial activities that could refer to starting new businesses, acting entrepreneurially within organizations, being innovative and socially active. In addition to the high level of intolerance of uncertainty, the results of the present study showed that people with pronounced extroversion are curious, optimistic, with strong self-efficacy, conscientiousness and openness to experience.

The studies investigating five-factor model by comparing entrepreneurs and managers have shown that conscientiousness, openness to experience and extraversion are more domi- 
nant traits in entrepreneurs than in managers and this study also demonstrated that an elevated level of one of these traits is followed by elevated levels of the other two traits. People with a high degree of openness to experience take on risks given that they prefer novelty and challenges, while people with high levels of neuroticism are not prone to taking risks and badly react to uncertainty (Costa \& McCrae, 1992). Results of this study have shown that a higher degree of openness to experience leads to increased levels of positive affect and conscientiousness, as well as to pronounced curiosity and self-efficacy, which supports the previous findings that people with a high degree of openness like novelty and challenges. Furthermore, this research supports the conclusion that a high degree of neuroticism leads to increased intolerance of uncertainty and worry, and that such people are not prone to taking risks.

Given that behavior occurs in accordance with an individual's personality, it is plausible to expect that entrepreneurial behavior will also be in function with personality traits. Personal characteristics of the entrepreneur (individual) represent one of the four Gartner's dimensions for creation of a new venture (Gartner, 1985). Some of the traits that had been defined as important antecedents of entrepreneurial behavior and success throughout the literature are need for achievement, locus of control, self-efficacy, risk-taking propensity, family influence, work experience etc. There are many studies that are exploring impact of different traits on different entrepreneurial processes and actions (e.g. intentions, opportunity recognition, strategies, decision making, success). Molino et al. (2018) have tested personality and social support as determinants of entrepreneurial intention in the Italian context and found that men scored higher levels of self-efficacy and internal locus of control than women. These findings are not in line with the present research, as it has not been found any statistically significant difference among women and men with respect to self-efficacy and externalization as opposite of internal locus of control.

\section{Conclusions}

Research on personality traits from the gender perspective is underdeveloped in the entrepreneurship literature. Combining the Big Five personality traits with those specific for entrepreneurs, statistical analysis showed that there were no statistically significant differences regarding all the tested traits in men and women, except for the degree of worry. The worry is directly related to feelings of insecurity and intolerance of uncertainty. A higher degree of worry leads to increased negative affect and a higher level of intolerance of uncertainty. In the literature, women have been mainly characterized as insecure compared to men, and some slight statistically significant difference could, therefore, be expected in women compared to men. These results could, to some extent, help to explain gender bias observed in the field of entrepreneurship. As suggested in the literature, personality traits could be useful tools for entrepreneurial success promotion and organization should take into consideration personality traits when selecting entrepreneurial individuals. Creation of the training programs that are helping woman to overcome the potential obstacle caused by a higher degree of the worry and encouraging them to employ genetically given traits would stimulate new venture creation, positively resulting in better social and economic performance. Encouragement of entrepreneurial activities is recommended as a way to stimulate economic growth, and en- 
trepreneurial ventures represent incubators of innovative products and market growth. Apart from the training programs, it is also important for creation of educational initiatives with a goal to increase students' knowledge and skills on entrepreneurship, to provide access to business contacts and networking, through the provision of different courses and workshops within the university context. Providing these conditions young entrepreneurs would have a chance to gain knowledge and develop capabilities for recognition and exploitation of entrepreneurial opportunities. That is why, the sample of students might be a good fit for investigating entrepreneurial traits. The number of female entrepreneurs is, in the most countries, under the average, so it is very important to investigate all the factors that might positively contribute to the development of the ventures. The present study has found that both man and woman are prone to exhibit the same personality profile defined with traits characterized with high degree of conscientiousness, openness and extraversion that, throughout the literature, has proved to have important impact on establishing and development of new ventures. The major constraints are socio- cultural features that differ from country to country, as the study is based in the Balkan area (Serbia and Bosnia and Herzegovina). This study is limited to the Universities from Balkan area. Further studies should include different countries in order to verify whether current findings could be transferred to the University students from different regions. In addition to general personality characteristics that have so far been used in the field of entrepreneurship, this study included the specific entrepreneurial characteristics such as locus of control, self-efficacy or intolerance of uncertainty into the research. Apart from the results showing there are no gender differences, this study gave a broader view of the interconnectivity and the statistical significance of entrepreneurial characteristics. In this way, an empirical basis for further research has been created, and a significant theoretical contribution has been provided to the study of entrepreneurship from the traits and gender perspectives.

\section{Disclosure statement}

Authors declare that they do not have any competing financial, professional, or personal interests from other parties.

\section{References}

Acker, J. (1992). From sex roles to gendered institutions. Contemporary Sociology: A Journal of Reviews, 21(5), 565-569. https://doi.org/10.2307/2075528

Ahl, H. (2004). The scientific reproduction of gender inequality. A discourse. Copenhagen Business School Press.

Ahl, H. (2006). Why research on women entrepreneurs needs new directions. Entrepreneurship Theory and Practice, 30(5), 595-621. https://doi.org/10.1111/j.1540-6520.2006.00138.x

Almobaireek, W. N., \& Manolova, T. S. (2013). Entrepreneurial motivations among female university youth in Saudi Arabia. Journal of Business Economics and Management, 14(Sup 1), S56-S75.

https://doi.org/10.3846/16111699.2012.711364 
Altinay, L., Madanoglu, M., Daniele, R., \& Lashley, C. (2012). The influence of family tradition and psychological traits on entrepreneurial intention. International Journal of Hospitality Management, 31(2), 489-499. https://doi.org/10.1016/j.ijhm.2011.07.007

Antoncic, B., Bratkovic Kregar, T., Singh, G., \& DeNoble, A. F. (2015). The big five personality-entrepreneurship relationship: evidence from Slovenia. Journal of Small Business Management, 53(3), 819-841. https://doi.org/10.1111/jsbm.12089

Baron, R. A. (2008). The role of affect in the entrepreneurial process. Academy of Management Review, 33(2), 328-340. https://doi.org/10.5465/amr.2008.31193166

Berenbaum, H., Bredemeier, K., \& Thompson, R. J. (2008). Intolerance of uncertainty: Exploring its dimensionality and associations with need for cognitive closure, psychopathology, and personality. Journal of Anxiety Disorders, 22(1), 117-125. https://doi.org/10.1016/j.janxdis.2007.01.004

Berle, D., Starcevic, V., Moses, K., Hannan, A., Milicevic, D., \& Sammut, P. (2011). Preliminary validation of an ultra-brief version of the Penn State Worry Questionnaire. Clinical Psychology \& Psychotherapy, 18(4), 339-346. https://doi.org/10.1002/cpp.724

Bernardino, S., Freitas Santos, J., \& Cadima Ribeiro, J. (2018). Social entrepreneur and gender: what's personality got to do with it? International Journal of Gender and Entrepreneurship, 10(1), 61-82. https://doi.org/10.1108/IJGE-07-2017-0040

Bezinović, P., \& Savčić, D. (1989). Lokus kontrole i njegovo mjerenje: prikaz nove skale za mjerenje eksternalne orijentacije. Psihologija, 22(1-2), 132-140.

Bhuian, S. N., Menguc, B., \& Bell, S. J. (2005). Just entrepreneurial enough: The moderating effect of entrepreneurship on the relationship between market orientation and performance. Journal of Business Research, 58(1), 9-17. https://doi.org/10.1016/S0148-2963(03)00074-2

Bird, B., \& Brush, C. (2002). A gendered perspective on organizational creation. Entrepreneurship: Theory and Practice, 26(3), 41-66. https://doi.org/10.1177/104225870202600303

Brandstätter, H. (2011). Personality aspects of entrepreneurship: A look at five meta-analyses. Personality and Individual Differences, 51(3), 222-230. https://doi.org/10.1016/j.paid.2010.07.007

Bruni, A., Gherardi, S., \& Poggio, B. (2004). Entrepreneur-mentality, gender and the study of women entrepreneurs. Journal of Organizational Change Management, 17(3), 256-268. https://doi.org/10.1108/09534810410538315

Busenitz, L. W., \& Barney, J. B. (1997). Differences between entrepreneurs and managers in large organizations: Biases and heuristics in strategic decision-making. Journal of Business Venturing, 12(1), 9-30. https://doi.org/10.1016/S0883-9026(96)00003-1

Caliendo, M., Fossen, F. M., \& Kritikos, A. S. (2011). Personality characteristics and the decision to become and stay self-employed (IZA and DIW Working Paper). https://doi.org/10.2139/ssrn.1793171

Carland, J. A. C., \& Carland, J. W. (1991). An empirical investigation into the distinctions between male and female entrepreneurs and managers. International Small Business Journal, 9(3), 62-72. https://doi.org/10.1177/026624269100900304

Carleton, R. N., Norton, M. P. J., \& Asmundson, G. J. (2007). Fearing the unknown: A short version of the Intolerance of Uncertainty Scale. Journal of Anxiety Disorders, 21(1), 105-117. https://doi.org/10.1016/j.janxdis.2006.03.014

Carver, C. (2003). Pleasure as a sign you can attend to something else: Placing positive feelings within a general model of affect. Cognition \& Emotion, 17(2), 241-261. https://doi.org/10.1080/02699930302294

Chaganti, R. (1986). Management in women-owned enterprises. Journal of Small Business Management, 24(4), 18-29. 
Čolović, P., Smederevac, S., \& Mitrović, D. (2014). Velikih pet plus dva: skraćena verzija. Primenjena psihologija, Dodatak, 7(3-1), 227-254. https://doi.org/10.19090/pp.2014.3-1.227-254

Costa, P. T., \& McCrae, R. R. (1992). Four ways five factors are basic. Personality and Individual Differences, 13(6), 653-665. https://doi.org/10.1016/0191-8869(92)90236-I

Direnfeld, D. M., \& Roberts, J. E. (2006). Mood congruent memory in dysphoria: The roles of state affect and cognitive style. Behaviour Research and Therapy, 44(9), 1275-1285. https://doi.org/10.1016/j.brat.2005.03.014

Dugas, M. J., Schwartz, A., \& Francis, K. (2004). Brief report: Intolerance of uncertainty, worry, and depression. Cognitive Therapy and Research, 28(6), 835-842. https://doi.org/10.1007/s10608-004-0669-0

Fairlie, R. W., \& Holleran, W. (2012). Entrepreneurship training, risk aversion and other personality traits: Evidence from a random experiment. Journal of Economic Psychology, 33(2), 366-378. https://doi.org/10.1016/j.joep.2011.02.001

Farrukh, M., Alzubi, Y., Shahzad, I. A., Waheed, A., \& Kanwal, N. (2018). Entrepreneurial intentions: The role of personality traits in perspective of theory of planned behaviour. Asia Pacific Journal of Innovation and Entrepreneurship, 12(3), 399-414. https://doi.org/10.1108/APJIE-01-2018-0004

Fleeson, W. (2001). Toward a structure-and process-integrated view of personality: Traits as density distributions of states. Journal of Personality and Social Psychology, 80(6), 1011-1027. https://doi.org/10.1037/0022-3514.80.6.1011

Freeston, M., Rhéaume, J., Letarte, H., Dugas, M. J., \& Ladouceur, R. (1994). Why do people worry? Personality and Individual Differences, 17(6), 791-802. https://doi.org/10.1016/0191-8869(94)90048-5

Gartner, W. B. (1985). A conceptual framework for describing the phenomenon of new venture creation. The Academy of Management Review, 10(4), 696-706. https://doi.org/10.2307/258039

Gavrilov-Jerković, V., Jovanović, V., Žuljević, D., \& Brdarić, D. (2013). When less is more: A short version of the personal optimism scale and the self-efficacy optimism scale. Journal of Happiness Studies, 15(2), 455-474. https://doi.org/10.1007/s10902-013-9432-0

Greene, F. J., Han, L., \& Marlow, S. (2013). Like mother, like daughter? Analyzing maternal influences upon women's entrepreneurial propensity. Entrepreneurship Theory and Practice, 37(4), 687-711. https://doi.org/10.1111/j.1540-6520.2011.00484.x

Gunkel, M., Lusk, E. J., Wolff, B., \& Li, F. (2007). Gender-specific effects at work: An empirical study of four countries. Gender, Work \& Organization, 14(1), 56-79. https://doi.org/10.1111/j.1468-0432.2007.00332.x

Gürol, Y., \& Atsan, N. (2006). Entrepreneurial characteristics amongst university students: Some insights for entrepreneurship education and training in Turkey. Education+Training, 48(1), 25-38. https://doi.org/10.1108/00400910610645716

Hisrich, R. D. (1990). Entrepreneurship/intrapreneurship. American Psychologist, 45(2), 209-222. https://doi.org/10.1037/0003-066X.45.2.209

Jennings, J. E., \& Brush, C. G. (2013). Research on women entrepreneurs: challenges to (and from) the broader entrepreneurship literature? The Academy of Management Annals, 7(1), 663-715. https://doi.org/10.5465/19416520.2013.782190

John, O. P., Naumann, L. A. P., \& Soto, C. J. (2008). Paradigm shift to the integrative Big Five trait taxonomy. In O. P. John, R. W. Robins, \& L. A. Pervin (Eds.), Handbook of personality: Theory and research (pp. 114-158). The Guilford Press.

Joksimović, S., \& Janjetović, D. (2008). Pojam o sebi i vrednosne orijentacije adolescenata. Zbornik Instituta za pedagoška istraživanja, 40(2), 288-305. https://doi.org/10.2298/ZIPI0802288J

Jovanović, J., \& Jerković, I. (2012). Conscientious students: more successful at school, none the happier for it. Zbornik Instituta za pedagoška istraživanja, 44(1), 59-73.

https://doi.org/10.2298/ZIPI1201059J 
Kalnins, A., \& Williams, M. (2014). When do female-owned businesses out-survive male-owned businesses? A disaggregated approach by industry and geography. Journal of Business Venturing, 29(6), 822-835. https://doi.org/10.1016/j.jbusvent.2013.12.001

Kashdan, T. B., Gallagher, M. W., Silvia, P. J., Winterstein, B. P., Breen, W. E., Terhar, D. J., \& Steger, M. F. (2009). The curiosity and exploration inventory-II: Development, factor structure, and psychometrics. Journal of Research in Personality, 43(6), 987-998. https://doi.org/10.1016/j.jrp.2009.04.011

Kashdan, T. B., Rose, P., \& Fincham, F. D. (2004). Curiosity and exploration: Facilitating positive subjective experiences and personal growth opportunities. Journal of Personality Assessment, 82(3), 291-305. https://doi.org/10.1207/s15327752jpa8203_05

Knatko, D., Shirokova, G., \& Bogatyreva, K. (2016). Industry choice by young entrepreneurs in different country settings: the role of human and financial capital. Journal of Business Economics and Management, 17(4), 613-627. https://doi.org/10.3846/16111699.2015.1113199

Knight, G. (2000). Entrepreneurship and marketing strategy: The SME under globalization. Journal of International Marketing, 8(2), 12-32. https://doi.org/10.1509/jimk.8.2.12.19620

Leutner, F., Ahmetoglu, G., Akhtar, R., \& Chamorro-Premuzic, T. (2014). The relationship between the entrepreneurial personality and the Big Five personality traits. Personality and Individual Differences, 63, 58-63. https://doi.org/10.1016/j.paid.2014.01.042

MacLeod, A. K., Williams, J. M., \& Bekerian, D. A. (1991). Worry is reasonable: the role of explanations in pessimism about future personal events. Journal of Abnormal Psychology, 100(4), 478-486. https://doi.org/10.1037/0021-843X.100.4.478

Marlow, S., \& Martinez Dy, A. (2018). Annual review article: Is it time to rethink the gender agenda in entrepreneurship research? International Small Business Journal, 36(1), 3-22. https://doi.org/10.1177/0266242617738321

Masters, R., \& Meier, R. (1988). Sex differences and risk-taking propensity of entrepreneurs. Journal of Small Business Management, 26(1), 31-35.

McClelland, D. C. (1961). The achieving society. D. Van Nostrand. https://doi.org/10.1037/14359-000

McMullen, J. S., \& Shepherd, D. A. (2006). Entrepreneurial action and the role of uncertainty in the theory of the entrepreneur. Academy of Management Review, 31(1), 132-152. https://doi.org/10.5465/amr.2006.19379628

Meyer, T. J., Miller, M. L., Metzger, R. L., \& Borkovec, T. D. (1990). Development and validation of the Penn State worry questionnaire. Behaviour Research and Therapy, 28(6), 487-495. https://doi.org/10.1016/0005-7967(90)90135-6

Mihić, L., Novović, Z., Čolović, P., \& Smederevac, S. (2014). Serbian adaptation of the Positive and Negative Affect Schedule (PANAS): Its facets and second-order structure. Psihologija, 47(4), 393-414. https://doi.org/10.2298/PSI1404393M

Molino, M., Dolce, V., Cortese, C. G., \& Ghislieri, C. (2018). Personality and social support as determinants of entrepreneurial intention. Gender differences in Italy. PloS ONE, 13(6), e0199924. https://doi.org/10.1371/journal.pone.0199924

Mueller, S. L. (2004). Gender gaps in potential for entrepreneurship across countries and cultures. Journal of Developmental Entrepreneurship, 9(3), 199-220.

Mueller, S. L., \& Thomas, A. S. (2001). Culture and entrepreneurial potential: A nine country study of locus of control and innovativeness. Journal of Business Venturing, 16(1), 51-75. https://doi.org/10.1016/S0883-9026(99)00039-7

Murugesan, R., \& Jayavelu, R. (2017). The influence of big five personality traits and self-efficacy on entrepreneurial intention: The role of gender. Journal of Entrepreneurship and Innovation in Emerging Economies, 3(1), 41-61. https://doi.org/10.1177/2393957516684569 
Ndubisi, N. (2008). Gender differences in entrepreneurial traits, perceptions and usage of information and communication technologies. Academy of Entrepreneurship Journal, 14(2), 107-121.

Palmer, C., Niemand, T., Stöckmann, C., Kraus, S., \& Kailer, N. (2019). The interplay of entrepreneurial orientation and psychological traits in explaining firm performance. Journal of Business Research, 94, 183-194. https://doi.org/10.1016/j.jbusres.2017.10.005

Rauch, A., \& Frese, M. (2007). Let's put the person back into entrepreneurship research: A meta-analysis on the relationship between business owners' personality traits, business creation, and success. European Journal of Work and Organizational Psychology, 16(4), 353-385. https://doi.org/10.1080/13594320701595438

Saridakis, G., Marlow, S., \& Storey, D. J. (2014). Do different factors explain male and female selfemployment rates? Journal of Business Venturing, 29(3), 345-362. https://doi.org/10.1016/j.jbusvent.2013.04.004

Schumpeter, J. A. (1934). The theory of economic development: An inquiry into profits, capital, credit, interest, and the business cycle (vol. 55). Transaction Publishers.

Schwartz, E. B. (1976). Entrepreneurship-New female frontier. Journal of Contemporary Business, 5(1), $47-76$.

Schweizer, K., \& Koch, W. (2001). The assessment of components of optimism by POSO-E. Personality and Individual Differences, 31(4), 563-574. https://doi.org/10.1016/S0191-8869(00)00161-6

Sexton, D. L. (1989). Research on women's business owners'. Women Owned Businesses. Praeger.

Sexton, D. L., \& Bowman-Upton, N. (1990). Female and male entrepreneurs: Psychological characteristics and their role in gender-related discrimination. Journal of Business Venturing, 5(1), 29-36. https://doi.org/10.1016/0883-9026(90)90024-N

Smederevac, S., Mitrović, D., \& Čolović, P. (2010). Velikih pet plus dva, primena i interpretacija. Centar za primenjenu psihologiju.

Van Ewijk, A. R., \& Belghiti-Mahut, S. (2019). Context, gender and entrepreneurial intentions: How entrepreneurship education changes the equation. International Journal of Gender and Entrepreneurship, 11(1), 75-98. https://doi.org/10.1108/IJGE-05-2018-0054

Watson, D., \& Clark, L. A. (1999). The PANAS-X: Manual for the positive and negative affect scheduleexpanded form. https://doi.org/10.17077/48vt-m4t2

Zhao, H., \& Seibert, S. E. (2006). The big five personality dimensions and entrepreneurial status: A meta-analytical review. Journal of Applied Psychology, 91(2), 259-271. https://doi.org/10.1037/0021-9010.91.2.259

Zhao, H., Seibert, S. E., \& Lumpkin, G. T. (2010). The relationship of personality to entrepreneurial intentions and performance: A meta-analytic review. Journal of Management, 36(2), 381-404. https://doi.org/10.1177/0149206309335187 